\title{
In Vitro Regeneration of Endangered Medicinal Hypoxis Species
}

\author{
Busie E. B. Nsibande ${ }^{1,2}$, Xueyuan Li' ${ }^{1}$ Annelie Ahlman'1, Li-Hua Zhu1* \\ ${ }^{1}$ Department of Plant Breeding, Swedish Agricultural University, Alnarp, Sweden \\ ${ }^{2}$ National Plant Genetic Resources Centre and Mushroom Development Unit, Malkerns, Swaziland \\ Email: ${ }^{*}$ Li-Hua.Zhu@slu.se
}

Received 20 September 2015; accepted 18 October 2015; published 21 October 2015

Copyright (C) 2015 by authors and Scientific Research Publishing Inc.

This work is licensed under the Creative Commons Attribution International License (CC BY).

http://creativecommons.org/licenses/by/4.0/

(c) (i) Open Access

\section{Abstract}

The genus Hypoxis contains some of southern Africa's most important wild medicinal species, a situation that has placed most of them amongst endangered species facing extinction. In this study, four Hypoxis species collected from Swaziland: $\mathrm{H}$. argentea, $\mathrm{H}$. filiformis, $\mathrm{H}$. acuminata and $\mathrm{H}$. hemerocallidea, were included to assess their potential for in vitro propagation in order to efficiently conserve these species in the future. Among all types of explants tested only corm explants and seeds gave rise to shoots under the in vitro conditions. For the corm establishment, $\boldsymbol{H}$. filiformis was the most in vitro responsive species, which had $100 \%$ shoot regeneration with high shoot number when cultured on the MS medium supplemented with $3 \mathrm{mg} \cdot \mathrm{l}^{-1}$ kinetin with a piece of shoot attached, while the highest mean shoot number (17) was obtained on the same medium, but with no shoot attachment to the corm explants. $\mathrm{H}$. argentea was the next most responsive species in vitro with up to $70 \%$ establishment, while the other two species had only up to $20 \%$ of in vitro establishment. For the seed explants, up to $29 \%$ seed germination was obtained for $\boldsymbol{H}$. argentea when the seed coats were crushed before the in vitro culture. The regenerated shoots were rooted in vitro and acclimatized in the greenhouse successfully

\section{Keywords}

Corm, Seed, Micropropagation, Plant Growth Regulators

\section{Introduction}

Species of the genus Hypoxis, belonging to the family Hypoxidaceae [1]-[4], are monocotyledons that are commonly distributed in the Southern Hemisphere [5] including sub-Saharan Africa, America, south-east Asia and Australia [6]. The genus Hypoxis consists of about 90 species, of which 30 are found in southern Africa [3]. The

${ }^{*}$ Corresponding author. 
fleshy corm acts as a survival mechanism that enables the plant to withstand cold conditions, drought, and fire [6] and contains medicinal compounds. The corms of some species are also used as a source of food by some southern African tribes in times of famine [3].

The genus has generated pharmaceutical interest based on its use as a traditional medicine by indigenous people of eastern and southern Africa [7]. Eleven species are reported to be used in southern Africa for medicinal purposes, whilst $H$. hemerocallidea and $H$. colchicifolia are reportedly the most popular ones [3] [4], a situation that places these species under threat [3]. Extracts from the corms of Hypoxis are used as ingredients in a wide range of products such as anti-oxidants, anti-inflammatories, anti-diabetics and anti-convulsants [8] [9]. $H$. hemerocallidea, or African potato, is counted amongst the special indigenous medicinal species of commercial importance in southern Africa [10]. It derives its value from the hypoxoside content, a sterol that is converted by the human body to rooperol, a biologically active compound that balances the human immune system, and thus offering great potential as a source of new drugs with immune-modulatory properties [3]. African potato is used commonly as an immune booster to treat many ailments [3] [11] [12], and for its nutritional value [12].

Besides hypoxoside, acuminoside, a geraniol glycoside was also isolated from $H$. acuminate [13], while ellagic acid, a natural phenol antioxidant compound with a rigid structure and poor solubility, was found in the only monocotyledonous species $\mathrm{H}$. filiformis [14].

Although Hypoxis species are naturally regenerated by seeds, they are difficult to propagate by seeds because the seeds seem to have a very strong seed coat or deep dormancy [15]. Vegetative propagation of Hypoxis species is still very uncommon in practice [4]. However, micropropagation may provide an alternative method for propagating species of this genus en masse to help prevent further depletion due to over-harvesting and preserve the valuable wild species. Very few studies on in vitro regeneration and establishment of Hypoxis have been reported, with varying levels of success: $H$. hemerocallidea (= H. rooperii) [2] [6] [16] [17], H. obtuse [1] [6], H. acuminataand $H$. rigidula [6], $H$. angustifolia [15], and $H$. colchicifolia [4]. The regeneration frequency in these studies varied a lot depending on species and culture medium. Some reports did not provide detailed information about the shoot regeneration frequency thus making it difficult to understand how well the protocols worked. Moreover, there is very limited report on successful in vitro seed germination. Appleton et al. [4] reported that only one seed germinated in vitro, which died of browning shortly after. It is thus important to optimize the current protocols and to develop new protocols for new species. As Hypoxis is a large genus, developing efficient vegetative production systems or approaches involving more species will help not only alleviate the pressure on the natural populations, but also contribute to the conservation of many valuable wild Hypoxis species.

The aim of this study was to assess the potential for mass propagating four natural Hypoxis species which are widely growing in Swaziland through the in vitro regeneration approach. We have been able to successfully establish all the four species in vitro and three ex vitro; to the authors' knowledge no in vitro regeneration has previously been reported for the species $H$. filiformis.

\section{Materials and Methods}

\subsection{Plant Materials}

Four species of Hypoxis naturally growing in Swaziland were used in this study: Hypoxis acuminata Baker, Hypoxis argentea Harv. ex Baker, Hypoxis hemerocallidea Firsch and Ave'-Lall, and Hypoxis filiformis Baker. Specimens of the species were identified at the National Herbarium, Swaziland. Corms of the four species were planted in 2:1 planting soil to sand mixture in the greenhouse at the Swedish University of Agricultural Sciences (SLU), Alnarp, Sweden.

\subsection{Preparation and Sterilization of Explants}

Seeds, leaves, shoot apexes, basal parts of inflorescence peduncles, and flower buds were surface sterilized in $6 \%$ calcium hypochlorite $\left(\mathrm{Ca}(\mathrm{ClO})_{2}\right)$ solution with Tween 20 on a shaker for $15 \mathrm{~min}$, followed by 3 rinses with sterile distilled water before being cultured on the culture medium. Roots were first washed at length in running tap water, followed by washing in $70 \%$ alcohol for 5 min and then with $6 \% \mathrm{Ca}(\mathrm{ClO})_{2}$ with Tween 20 for 15 min. For corms, a modification of the protocol described by Ndong et al. [2] was used. The corms were first washed at length in running tap water with a detergent, followed by washing in $70 \%$ alcohol for $5 \mathrm{~min}$, and then washing in $6 \% \mathrm{Ca}(\mathrm{ClO})_{2}$ with Tween 20 and shaking for $30 \mathrm{~min}$. The outer epidermal tissues were then removed with a 
knife and the corms were cut into large pieces, approximately $3.0 \mathrm{~cm}^{2}$ thick, and washed in $6 \% \mathrm{Ca}(\mathrm{ClO})_{2}$ with Tween 20 for 15 min, followed by 3 rinses with sterile distilled water. They were then cut into smaller pieces of approximately $0.5-1.0 \mathrm{~cm}^{2}$ thick before being placed on the culture medium.

\subsection{Culture Media and Treatment}

MS [18] medium containing $30.0 \mathrm{~g} \cdot \mathrm{l}^{-1}$ sucrose, $8.0 \mathrm{~g} \cdot \mathrm{l}^{-1}$ Bacto agar, and 1.0\% activated charcoal was used as the basal medium. Plant growth regulators (PGRs), mainly auxins indole-3-acetic acid (IAA), and naphthaleneacetic acid (NAA), and cytokininsbenzyladenine (BA) and kinetin (Kin), either alone or in combination, were added in the basal medium. Medium was changed regularly and the frequency depended on the requirement such as browning, contamination or infection of cultures. The $\mathrm{pH}$ was adjusted to 5.8 before adding agar and activated charcoal. Explants were either maintained in the same medium or transferred to other media (details are provided in the result section).

\subsection{Culture of Seeds}

Seeds were obtained from $H$. argentea, $H$. filiformis, and $H$. hemerocallidea. The seeds, harvested from the plants grown in the greenhouse were surface sterilized as described in 2.2 and subsequently cultured on the half-strength MS medium free of PGRs. Both intact seeds and seeds crushed with forceps were cultured. Once germinated the young seedlings were transferred to the full-strength MS without PGRs.

\subsection{Leaf Culture}

Young leaves of H. acuminata, $H$. filiformis and $H$. hemerocallidea were harvested, washed and cut into pieces before being surface sterilized as described in 2.2. Following sterilization, leaves were further cut into smaller pieces of approximately $0.5 \mathrm{~cm}^{2}$ before being placed on the basal MS medium supplemented with $0.5 \mathrm{mg} \cdot \mathrm{l}^{-1}$. Untreated leaves were used as the control.

\subsection{Culture of Flower Buds}

Unopened flower buds of $H$. argentea, $H$. filiformis and $H$. hemerocallidea were first washed and sterilized as described in 2.2 above. The buds were cut into half below the perianth segment and the top part was removed and the lower part cultured in double basal-strength MS containing $30.0 \mathrm{~g} \cdot \mathrm{l}^{-1}$ sucrose, $0.1 \mathrm{~g} \cdot \mathrm{l}^{-1}$ myo-inositol, 1.0 $\mathrm{g} \cdot \mathrm{l}^{-1}$ casein hydrolysate, a modification of the protocol used by Appleton et al. [4]. Flower buds that were cultured on normal full-strength MS were used as the control.

\subsection{Root Culture}

Roots for $H$. acuminata, $H$. filiformis, and $H$. hemerocallidea were cleaned and sterilized using the protocol described in 2.2. The roots were then cut into small pieces of about $0.5-1.0 \mathrm{~cm}$ in length and cultured on the basal medium with supplemented with either no PGR, or $0.5 \mathrm{mg} \cdot \mathrm{l}^{-1} \mathrm{BA}$, or $2.0 \mathrm{mg} \cdot \mathrm{l}^{-1} \mathrm{BA}$ or $1.0 \mathrm{mg} \cdot \mathrm{l}^{-1} \mathrm{Kin}$, or 3.0 $\mathrm{mg} \cdot \mathrm{l}^{-1}$ Kin.

\subsection{Culture of Corms}

Corms were cleaned and prepared as described in 2.2 above before culturing. To save on plant material, a non-destructive strategy was devised where only part of the corm was used whilst the rest remained attached to the plant in the greenhouse and the plant survived and continued growing. Corm explants were either cultured with or without a piece of shoot attached on either the basal MS medium alone or supplemented with $1.0 \mathrm{mg} \cdot \mathrm{l}^{-1}$ NAA, or $3.0 \mathrm{mg} \cdot l^{-1} \mathrm{BA}$, or $3.0 \mathrm{mg} \cdot l^{-1}$ kinetin, or $5.0 \mathrm{mg} \cdot l^{-1} \mathrm{BA}$, respectively. The explants were cultured on medium containing the same type and concentration of PGRs for the duration of the culture period or transferred to a medium of a different type and concentration.

\subsection{In Vitro Rooting and Acclimatization}

Well-developed shoots were either transferred to the basal MS supplemented with $2 \mathrm{mg} \cdot \mathrm{l}^{-1} \mathrm{BA}$ and $5 \mathrm{mg} \cdot \mathrm{l}^{-1}$ IAA, or to PGR free basal medium. Rooted shoots and seedlings were acclimatized in vitro by opening the cul- 
ture vehicle and leaving it open overnight in the growth chamber. The roots were washed with distilled water to remove all traces of agar before soaking in $0.1 \%$ mercuric chloride $\left(\mathrm{HgCl}_{2}\right)$ solution for 15 min and immersing in distilled water, leaving the leaves above the water level, for 5 days in the growth chamber.

\subsection{Culture Conditions}

All in vitro cultures were maintained in a growth chamber with the temperature of $25 / 18^{\circ} \mathrm{C}$ (day/night) and $16 \mathrm{~h}$ photoperiod at the light intensity of $40 \mu \mathrm{mol} \cdot \mathrm{m}^{-2} \cdot \mathrm{s}^{-1}$ provided by cool white fluorescent tubes.

\subsection{Acclimatization in Greenhouse}

Shoots were planted in compost soil mixed with sand (2:1) in the greenhouse and covered with transparent plastic cups for 7 to 10 days; thereafter the cups were partially lifted to allow the plantlets to adjust to the new conditions before being completely removed. Plantlets were watered every two days without wetting the leaves until they became hardened and well established.

\subsection{Statistical Analysis}

An analysis of variance and the Chi-square Two-way test were conducted using Minitab 16, as well as the Fisher's test for multiple comparison analysis. The number of explants ranged from 10 to 100, depending on material availability and all the experiments were repeated twice.

\section{Results}

\subsection{Culture of Seeds}

Seeds only germinated when the seed coat was crushed with forceps before being cultured (Figure 1), while intact seeds failed to germinate. Seed infection differed significantly among species with seeds of $H$. filiformis having the highest infection. Among the three species tested, the highest germination of $29.0 \%$ was obtained with $H$. argentea; whilst germination of this species commenced about two weeks after culture (Table 1), it took the other two species about one month to germinate. Some seeds of $H$. argentea and $H$. filiformis with the crushed seed coats formed callus that gave rise to multiple shoots. Since these shoots came from a single seed they were treated as one germinated seed. Up to 8 shoots were recorded arising from the callus of one seed in $H$. filiformis.
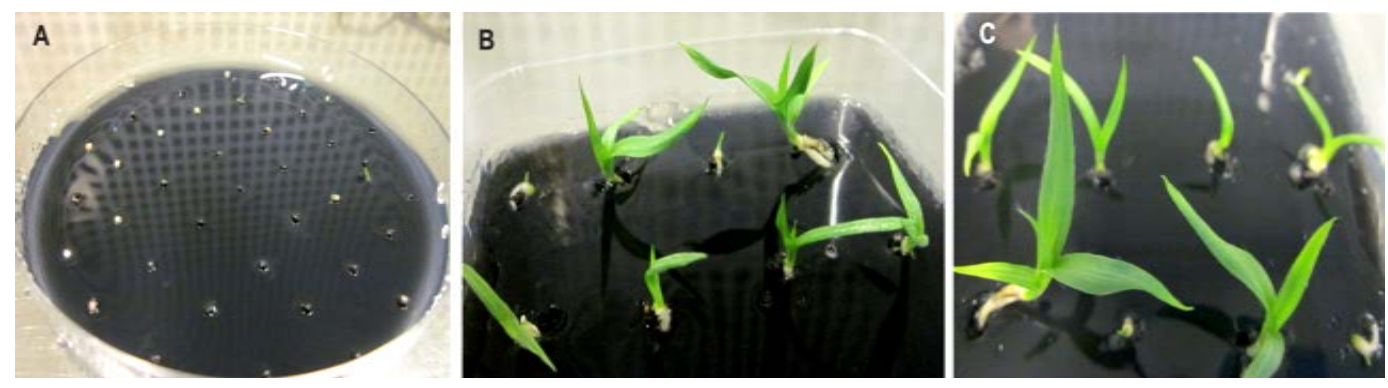

Figure 1. Germinating seeds of $H$. argenteawith the seed coat crushed grown initially on half-strength MS (left) and 5-week-old seedlings on full-strength MS (middle and right).

Table 1. Corm establishment of Table 1: Seed germination of Hypoxis species with crushed seed coats cultured on half-strength MS.

\begin{tabular}{cccc}
\hline Species & Total seed no. & Infection (\%) & Germination (\%) \\
\hline H. argentea & 100 & $4 \mathrm{~b}$ & $29.0 \mathrm{a}$ \\
H. filiformis & 100 & $18 \mathrm{a}$ & $12.0 \mathrm{~b}$ \\
H. hemerocallide & 15 & $0 \mathrm{~b}$ & $13.3 \mathrm{~b}$ \\
\hline
\end{tabular}

Figures sharing different letters within the same column indicate a significant difference at $\mathrm{p}=0.05$. 


\subsection{Culture of Corms}

\subsubsection{H. acuminata}

Nine out of the ten treatments responded to in vitro by producing callus, whilst six of them resulted in shoot regeneration, only one treatment produced shoots directly from the explants. Shoot regeneration varied from $0 \%$ to $20.0 \%$ among the different treatments, but there was no statistic difference among the treatments. It appears that this species only responded to Kin and BA for shoot regeneration, but not to NAA (Table 2). Infection ranged from $0 \%$ to $80 \%$, while callus formation was $0 \%$ to $50 \%$. Both infection and callus formation frequencies are not clearly related to the type and concentration of PGRs used (Table 2). Direct regeneration of explants cultured on the MS medium supplemented with $3 \mathrm{mg} \cdot \mathrm{l}^{-1} \mathrm{BA}$ was observed, whereas most of the treatments produced shoots via callus. In some treatments explants produced callus only, with no shoots or roots. Explants cultured on medium with a higher concentration of Kin (5 mg $\left.\cdot \mathrm{l}^{-1}\right)$ produced roots relatively earlier, and in most instances before shoots were formed (Figure 2). No significant difference was found in shoot regeneration from the corm explants cultured with shoot attached compared to those cultured without shoot on the same medium regardless of the presence or absence of PGR (compare treatments 1 and 2; 7 and 8; 9 and 10). Moreover, there was no significant difference either $(\mathrm{p}>0.05)$ among the treatments regarding the number of shoots produced per regenerated explant (Table 2).

\subsubsection{H. argentea}

Infection ranged from $5.6 \%$ to $70 \%$, while the callus formation frequency ranged from $12.5 \%$ to $80 \%$ for all

Table 2. Corm establishment of H. acuminata on different media after 24 weeks in vitro culture.

\begin{tabular}{cccccc}
\hline Code & Treatment & Infection (\%) & $\begin{array}{c}\text { Explants with } \\
\text { callus (\%) }\end{array}$ & $\begin{array}{c}\text { Explants with } \\
\text { shoots (\%) }\end{array}$ & $\begin{array}{c}\text { Shoot no/explant } \\
\text { (means } \pm \text { SE) }\end{array}$ \\
\hline 1 & MS & $24.0 \mathrm{~b}$ & $50.0 \mathrm{a}$ & $0 \mathrm{a}$ & - \\
2 & MS + shoot & $18.8 \mathrm{~b}$ & $12.5 \mathrm{~b}$ & $6.3 \mathrm{a}$ & $1.0 \pm 0 \mathrm{a}$ \\
3 & MS $\rightarrow 3$ Kin & $80.0 \mathrm{a}$ & $10.0 \mathrm{~b}$ & $20.0 \mathrm{a}$ & $2.0 \pm 0 \mathrm{a}$ \\
4 & MS $\rightarrow 5$ Kin & $80.0 \mathrm{a}$ & $20.0 \mathrm{ab}$ & $20.0 \mathrm{a}$ & $1.5 \pm 0.5 \mathrm{a}$ \\
5 & NAA & $33.3 \mathrm{~b}$ & $16.7 \mathrm{ab}$ & $0 \mathrm{a}$ & - \\
6 & NAA $\rightarrow 3$ Kin & $8.3 \mathrm{~b}$ & $25.0 \mathrm{ab}$ & $0 \mathrm{a}$ & - \\
7 & BA & $8.3 \mathrm{~b}$ & $50.0 \mathrm{a}$ & $16.7 \mathrm{a}$ & $2.0 \pm 1 \mathrm{a}$ \\
8 & BA + shoot & $80.0 \mathrm{a}$ & $0 \mathrm{~b}$ & $10.0 \mathrm{a}$ & $7.0 \pm 0 \mathrm{a}$ \\
9 & Kin & $8.3 \mathrm{~b}$ & $50.0 \mathrm{a}$ & $8.3 \mathrm{a}$ & $1.0 \pm 0 \mathrm{a}$ \\
10 & Kin + shoot & $16.7 \mathrm{~b}$ & $25.0 \mathrm{ab}$ & $16.7 \mathrm{a}$ & $4.0 \pm 3 \mathrm{a}$ \\
\hline
\end{tabular}

Note: 1 = PGR free MS; 2 = PGR free MS with shoot attached; 3 = PGR free MS to $3 \mathrm{mg} \cdot \mathrm{l}^{-1}$ kinetin (Kin); $4=$ PGR free MS to 5 $\mathrm{mg} \cdot \mathrm{l}^{-1} \mathrm{Kin} ; 5=1 \mathrm{mg} \cdot \mathrm{l}^{-1}$ NAA; $6=1 \mathrm{mg} \cdot \mathrm{l}^{-1}$ NAA for 3 weeks before being transferred to $3 \mathrm{mg} \cdot \mathrm{l}^{-1}$ kinetin; $7=3 \mathrm{mg} \cdot \mathrm{l}^{-1} \mathrm{BAP} ; 8=3$ $\mathrm{mg} \cdot \mathrm{l}^{-1}$ BAP with shoot attached; $9=3 \mathrm{mg} \cdot \mathrm{l}^{-1} \mathrm{Kin} ; 10=3 \mathrm{mg} \cdot \mathrm{l}^{-1}$ Kin with shoot attached. Figures sharing the same letter indicate that the treatments were not significant at $\mathrm{p}=0.05$.
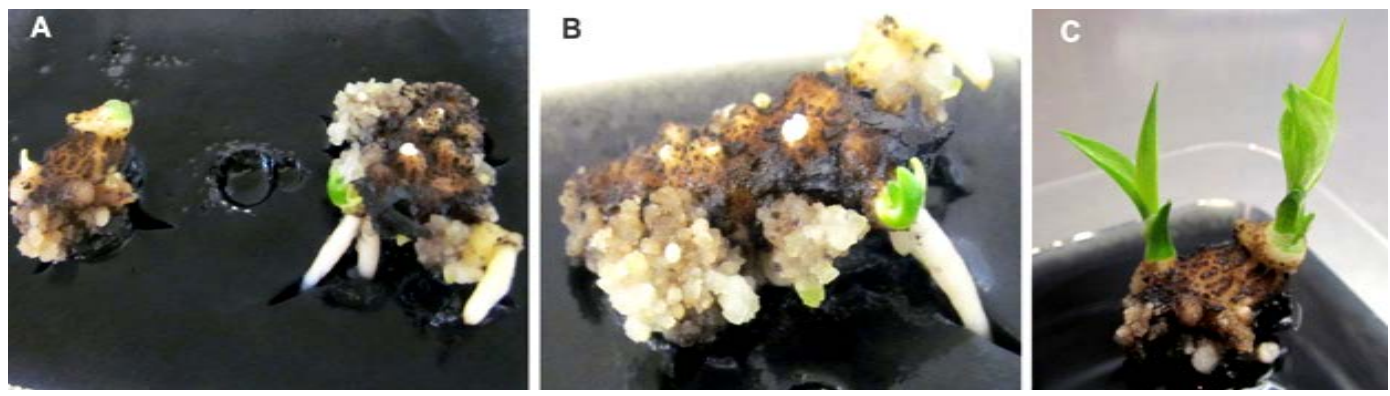

Figure 2. Corm explants of $H$. acuminata cultured on medium with $5 \mathrm{mg} \cdot \mathrm{l}^{-1}$ kinetin at different stages of development. A: Calli and roots; B: Calli, roots and emerging shoots; C: 9-week-old shoots through indirect regeneration via callus. 
treatments. The highest shoot regeneration (70\%), which was significantly higher than most of the other treatments, was obtained when the explants were cultured with a piece of shoot attached on the MS medium containing $3 \mathrm{mg} \cdot l^{-1}$ BA. This treatment also resulted in higher shoot number per regenerated explant compared to the majority of the treatments. The highest shoot frequency (7 shoots/explant) though was obtained from the explants cultured on the MS medium supplemented with $1 \mathrm{mg} \cdot \mathrm{l}^{-1}$ NAA (Table 3). There was no significant difference in the shoot regeneration frequency between explants cultured with or without shoot attachment on the MS medium free of PGRs (treatments 1 and 2), however, a significant regeneration was observed between the two types of explants in the presence of BA on the medium (treatments 3 and 4), but not in the presence of NAA (treatments 5 and 6) (Table 3). Generally regenerated shoots were formed from callus (Figure 3).

\subsubsection{H. filiformis}

Ten out of eleven treatments, including PGR free MS medium, produced shoots from corm explants. There were significant differences $(\mathrm{p}<0.05)$ in shoot regeneration among the treatments, and in the mean number of shoots produced per regenerated explant (Table 4). One hundred percent regeneration was obtained from corm explants cultured with a piece of shoot attached on the MS medium supplemented with $3 \mathrm{mg} \cdot \mathrm{l}^{-1}$ Kin (treatment 4), whereas the highest mean number (17) of shoots per regenerated explant was obtained on the same medium, but
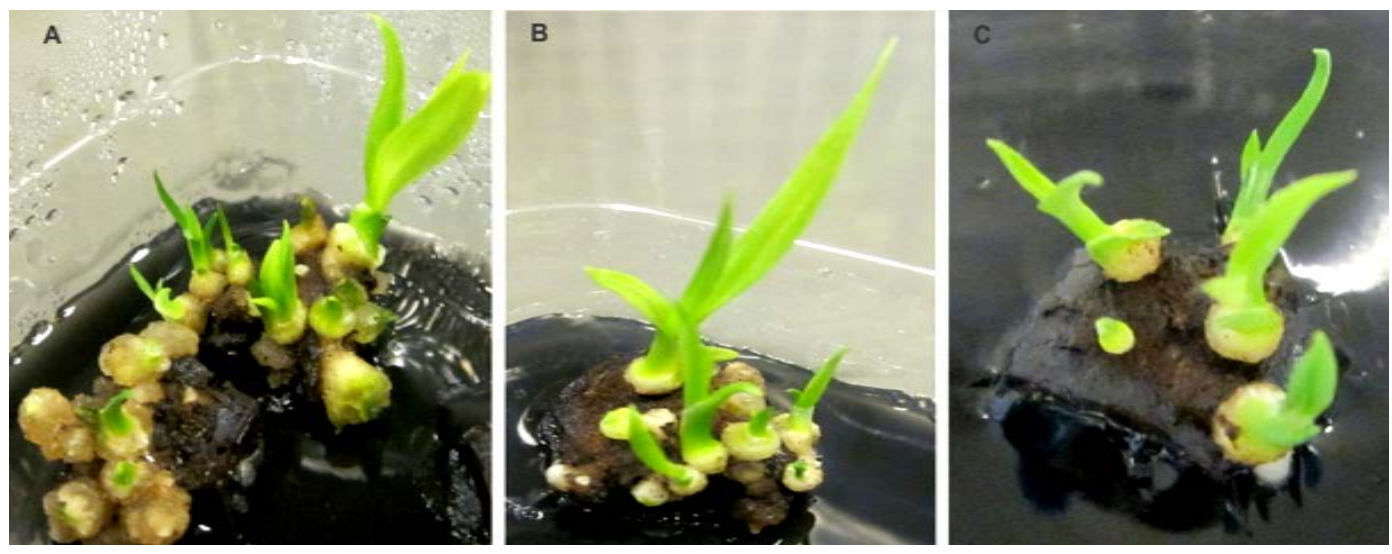

Figure 3. Shoots of $H$. argentea regenerated from corm explants cultured on MS medium supplemented with different PGRs. A: Callus and indirect shoots formed on medium with $3 \mathrm{mg} \cdot \mathrm{l}^{-1} \mathrm{BA}$; B and C: Shoots formed on medium with $1 \mathrm{mg} \cdot \mathrm{l}^{-1} \mathrm{NAA}$ for 5 weeks, followed $3 \mathrm{mg} \cdot \mathrm{l}^{-1} \mathrm{BA}(\mathrm{B})$ or $3 \mathrm{mg} \cdot \mathrm{l}^{-1} \mathrm{kinetin}(\mathrm{C})$.

Table 3. Corm establishment of $H$. argentea on different media after 24 weeks in vitro culture.

\begin{tabular}{|c|c|c|c|c|c|}
\hline Code & Treatment & Infection (\%) & Explants with callus (\%) & Explants with shoots (\%) & $\begin{array}{l}\text { Shoot no/explant } \\
\text { (means } \pm \text { SE) }\end{array}$ \\
\hline 1 & MS & 5.6 bcde & $27.8 \mathrm{bc}$ & $22.2 \mathrm{bc}$ & $1.8 \pm 0.5 \mathrm{~b}$ \\
\hline 2 & MS + shoot & 40.0 abcd & $30.0 \mathrm{bc}$ & $40.0 \mathrm{ab}$ & $1.3 \pm 0.3 \mathrm{~b}$ \\
\hline 3 & BA & 10.0 de & $15.0 \mathrm{c}$ & $0 \mathrm{c}$ & - \\
\hline 4 & $\mathrm{BA}+$ shoot & 30.0 bcde & $70.0 \mathrm{a}$ & $70.0 \mathrm{a}$ & $4.1 \pm 0.9 \mathrm{ab}$ \\
\hline 5 & NAA & $41.7 \mathrm{abc}$ & $50.0 \mathrm{ab}$ & $41.7 \mathrm{ab}$ & $7.2 \pm 3.0 \mathrm{a}$ \\
\hline 6 & $\mathrm{NAA}+$ shoot & $70.0 \mathrm{a}$ & $30.0 \mathrm{bc}$ & $0 \mathrm{c}$ & - \\
\hline 7 & $\mathrm{NAA} \rightarrow \mathrm{BA}$ & $60.0 \mathrm{ab}$ & $30.0 \mathrm{bc}$ & $20.0 \mathrm{bc}$ & $4.5 \pm 2.5 \mathrm{ab}$ \\
\hline 8 & $\mathrm{NAA} \rightarrow$ Kin & 25.0 cde & $12.5 \mathrm{c}$ & 18.8 bc & $3.0 \pm 1.0 \mathrm{ab}$ \\
\hline 9 & Kin & $33.3 \mathrm{bc}$ & $16.7 \mathrm{bc}$ & $22.2 \mathrm{bc}$ & $2.5 \pm 1.2 \mathrm{~b}$ \\
\hline
\end{tabular}

Note: 1 = PGR free MS; 2 = PGR free MS with shoot attached; $3=3 \mathrm{mg} \cdot \mathrm{l}^{-1} \mathrm{BA} ; 4=3 \mathrm{mg} \cdot \mathrm{l}^{-1} \mathrm{BA}$ with shoot; $5=1 \mathrm{mg} \cdot \mathrm{l}^{-1} \mathrm{NAA} ; 6=1 \mathrm{mg} \cdot \mathrm{l}^{-1} \mathrm{NAA}$ with shoot attached; $7=1 \mathrm{mg} \cdot \mathrm{l}^{-1}$ NAA for 3 weeks before being transferred to $3 \mathrm{mg} \cdot \mathrm{l}^{-1} \mathrm{BA} ; 8=1 \mathrm{mg} \cdot \mathrm{l}^{-1}$ NAA for 3 weeks before being transferred to $3 \mathrm{mg} \cdot \mathrm{l}^{-1}$ kinetin (Kin); $9=3 \mathrm{mg} \cdot \mathrm{l}^{-1}$ Kin. Figures sharing different letters within the same column indicate a significant difference at $\mathrm{p}=0.05$. 
Table 4. Corm establishment of $H$. filiformiscorm explants on different media after 24 weeks in vitro culture.

\begin{tabular}{|c|c|c|c|c|c|}
\hline Code & Treatment & Infection (\%) & $\begin{array}{l}\text { Explants with } \\
\text { callus (\%) }\end{array}$ & Explants with shoots (\%) & $\begin{array}{l}\text { Shoot no/explant } \\
\text { (means } \pm \text { SE) }\end{array}$ \\
\hline 1 & MS & $16.7 \mathrm{c}$ & $0 \mathrm{e}$ & 22.2 de & $1.5 \pm 0.5 \mathrm{~d}$ \\
\hline 2 & MS + shoot & $50.0 \mathrm{ab}$ & $50.0 \mathrm{bc}$ & $50.0 \mathrm{bcd}$ & $8.0 \pm 2.9 \mathrm{abc}$ \\
\hline 3 & Kin & $60.0 \mathrm{a}$ & 11.1 de & 11.1 de & $17.0 \pm 14.0 \mathrm{a}$ \\
\hline 4 & Kin + shoot & $0 \mathrm{c}$ & $100.0 \mathrm{a}$ & $100.0 \mathrm{a}$ & $4.0 \pm 0.7 \mathrm{bc}$ \\
\hline 5 & BA & $21.4 \mathrm{~b} \mathrm{c}$ & 28.6 cde & $0 \mathrm{e}$ & - \\
\hline 6 & $\mathrm{BA}+$ shoot & $0 \mathrm{c}$ & $80.0 \mathrm{ab}$ & $80.0 \mathrm{abc}$ & $4.3 \pm 0.5 \mathrm{bc}$ \\
\hline 7 & NAA & $29.4 \mathrm{abc}$ & $35.3 \mathrm{~cd}$ & 58.8 bc & $4.6 \pm 1.3 \mathrm{bcd}$ \\
\hline 8 & $\mathrm{NAA} \rightarrow \mathrm{BA}$ & $21.1 \mathrm{bc}$ & $73.7 \mathrm{ab}$ & $68.4 \mathrm{~b}$ & $6.4 \pm 1.3 \mathrm{bc}$ \\
\hline 9 & $\mathrm{NAA}+\mathrm{BA} \rightarrow \mathrm{BA}$ & $30.0 \mathrm{abc}$ & $70.0 \mathrm{ab}$ & $70.0 \mathrm{ab}$ & $10.0 \pm 3.7 \mathrm{ab}$ \\
\hline 10 & $\mathrm{NAA} \rightarrow 5 \mathrm{BA}$ & $21.4 \mathrm{bc}$ & 30.0 cde & 30.0 cde & $14.7 \pm 2.0 \mathrm{a}$ \\
\hline 11 & $\mathrm{NAA} \rightarrow$ Kin & $16.7 \mathrm{c}$ & $60.0 \mathrm{bc}$ & $10.0 \mathrm{e}$ & $10.0 \pm 0 \mathrm{ab}$ \\
\hline
\end{tabular}

Note: 1 = PGR free MS; 2 = PGR free MS with shoot attached; $3=3 \mathrm{mg} \cdot \mathrm{l}^{-1}$ kinetin (Kin); $4=3 \mathrm{mg} \cdot \mathrm{l}^{-1} \mathrm{Kin}$ with shoot attached; $5=3 \mathrm{mg} \cdot \mathrm{l}^{-1} \mathrm{BA} ; 6=$ $3 \mathrm{mg} \cdot l^{-1}$ BA with shoot attached; $7=1 \mathrm{mg} \cdot l^{-1} \mathrm{NAA} ; 8=1 \mathrm{mg} \cdot l^{-1} \mathrm{NAA}$ for 3 weeks before being transferred to $3 \mathrm{mg} \cdot l^{-1} \mathrm{BA} ; 9=1 \mathrm{mg} \cdot l^{-1} \mathrm{NAA}+3$ $\mathrm{mg} \cdot \mathrm{l}^{-1} \mathrm{BA}$ for 3 weeks before being transferred to $3 \mathrm{mg} \cdot \mathrm{l}^{-1} \mathrm{BA} ; 10=1 \mathrm{mg} \cdot \mathrm{l}^{-1}$ NAA to $5 \mathrm{mg} \cdot \mathrm{l}^{-1} \mathrm{BA} ; 11=1 \mathrm{mg} \cdot \mathrm{l}^{-1}$ NAA to $3 \mathrm{mg} \cdot l^{-1} \mathrm{Kin}$. Figures sharing different letters within the same column indicate a significant difference at $\mathrm{p}=0.05$.

without shoot attachment to the corm (treatment 3). This medium had only $11 \%$ explants giving rise to shoots (Figure 4). On both media, regenerated shoots were produced from callus which had equally the same callus and shoot formation frequencies of $100 \%$ and $11.1 \%$, respectively. One explant had up to 32 shoots formed when initially cultured on the MS supplemented with $1 \mathrm{mg} \cdot l^{-1} \mathrm{NAA}$ and $3 \mathrm{mg} \cdot \mathrm{l}^{-1} \mathrm{BA}$ for 3 weeks, followed by culture on MS supplemented with $3 \mathrm{mg} \cdot \mathrm{l}^{-1}$ BA (treatment 9). Notable differences in shoot regeneration and shoot frequency were also observed between corm explants cultured with or without shoot attachment in the absence of PGRs; explants with shoot attachment performed relatively better than those without and the shoot frequency was significantly higher (treatments 1 and 2). Additionally, the regeneration frequency was significantly higher for the explants with shoot attached than those without shoot regardless of PGR type (treatments 3 and 4; 5 and 6). Infection of explants during culture ranged between $0 \%$ and $60 \%$ with the largest number of shoots per regenerated explant arising from the treatment having the highest infection rate.

\subsubsection{H. hemerocallidea}

Corm explants of $H$. hemerocallidea took a very long time to respond to in vitro culture compared to the other three species, and the response was relatively poor with the majority of the treatments with no callus formation. Shoots were only produced when the explants were first cultured on the MS medium supplemented with 1 $\mathrm{mg} \cdot \mathrm{l}^{-1}$ NAA for 9 weeks before culturing on the MS medium supplemented with either $3 \mathrm{mg} \cdot \mathrm{l}^{-1} \mathrm{BA}$, or $3 \mathrm{mg} \cdot \mathrm{l}$ Kin, or $5 \mathrm{mg} \cdot \mathrm{l}$ Kin. The shoot number per regenerated explant was also low (Table 5). Direct shoots started developing 10 weeks after transfer to the MS medium supplemented with cytokinins and growth of the shoots was extremely slow. Explants of this species had the least infection compared to the other species with 4 treatments having $0 \%$ infection. Even though the least regeneration was achieved, most explants remained fresh and intact during the culture period.

\subsection{Culture of Other Explants}

All other types of explants including leaves, flower buds, roots, and inflorescence peduncles failed to regenerate in any of the media tested in all four species. The explants usually turned brown and had to be sub-cultured very frequently. Although the browning could be notably reduced when $1.0 \%$ activated charcoal was added in the media, still no any regeneration occurred during the culture period.

\subsection{Rooting of Regenerated Shoots in Vitro and Acclimatization in Vitro and ex Vitro}

Most shoots produced roots when transferred to either the PGR free MS medium or to the MS medium supple- 

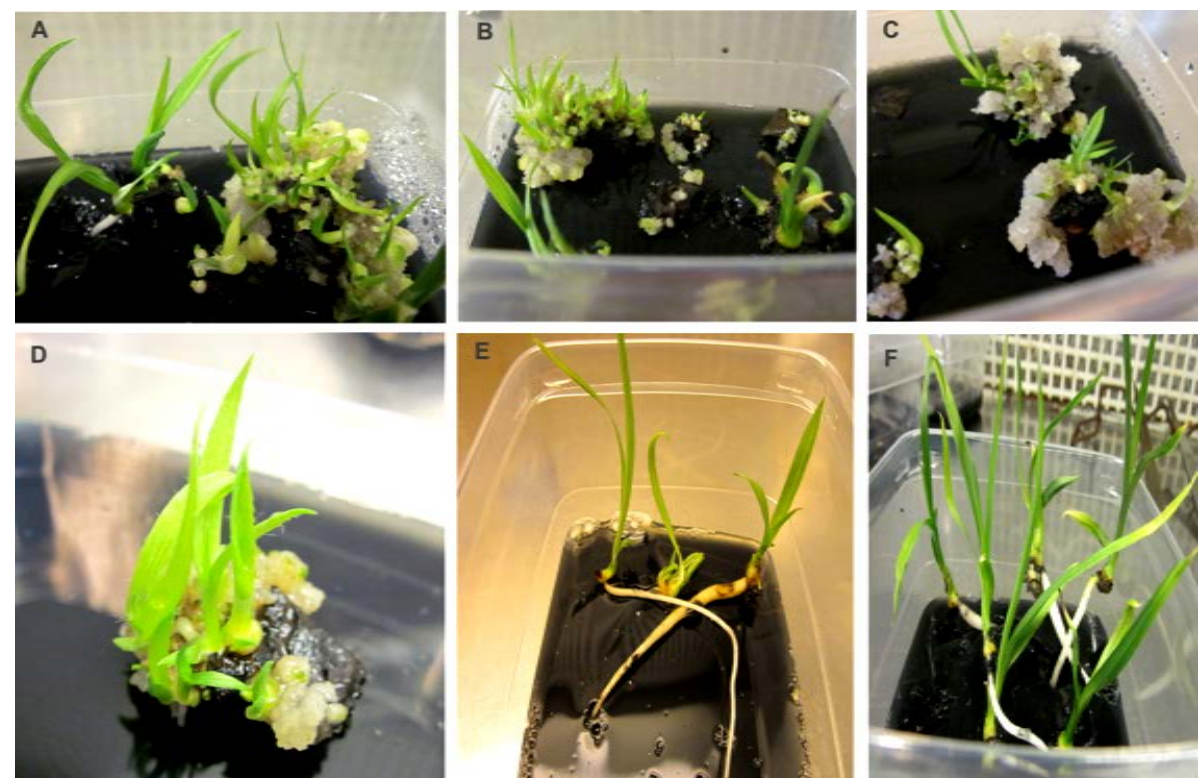

Figure 4. Shoots of $H$. filiformis regenerated from corm explants cultured on the MS medium supplemented with different PGRs. A: Callus and multiple shoots produced on medium supplemented with $1 \mathrm{mg} \cdot \mathrm{l}^{-1} \mathrm{NAA}$; B: Shoots produced on medium with $3 \mathrm{mg} \cdot \mathrm{l}^{-1} \mathrm{BA}$ following an initial culture with $1 \mathrm{mg} \cdot \mathrm{l}^{-1} \mathrm{NAA}$; C: Callus and shoots formed on medium with 5 $\mathrm{mg} \cdot \mathrm{l}^{-1}$ BA following an initial culture with $1 \mathrm{mg} \cdot \mathrm{l}^{-1} \mathrm{NAA}$; D: Corm explant with callus and multiple shoots on medium with $3 \mathrm{mg} \cdot \mathrm{l}^{-1}$ kinetin; E: 17 -week-old shoots with long roots on medium with $3 \mathrm{mg} \cdot \mathrm{l}^{-1} \mathrm{BA}$ following an initial culture with $1 \mathrm{mg} \cdot \mathrm{l}^{-1} \mathrm{NAA}$; F: Shoots rooted on medium with $2 \mathrm{mg} \cdot \mathrm{l}^{-1} \mathrm{BA}$ and $5 \mathrm{mg} \cdot \mathrm{l}^{-1} \mathrm{IAA}$.

Table 5. Response of $H$. hemerocallidea corm explants to different media after 24 weeks in vitro culture.

\begin{tabular}{|c|c|c|c|c|c|}
\hline Code & Treatment & Infection (\%) & $\begin{array}{l}\text { Explants with } \\
\text { callus (\%) }\end{array}$ & $\begin{array}{l}\text { Explants with shoots } \\
\text { (\%) }\end{array}$ & $\begin{array}{l}\text { Shoot no/explant } \\
\text { (means } \pm \text { SE) }\end{array}$ \\
\hline 1 & MS & $0 \mathrm{~b}$ & $0 \mathrm{~b}$ & $0 \mathrm{~b}$ & - \\
\hline 2 & MS + shoot & $10.0 \mathrm{~b}$ & $0 \mathrm{~b}$ & $0 \mathrm{~b}$ & - \\
\hline 3 & NAA & $0 \mathrm{~b}$ & $0 \mathrm{~b}$ & $0 \mathrm{~b}$ & - \\
\hline 4 & $\mathrm{NAA} \rightarrow$ kin & $70.0 \mathrm{a}$ & $0 \mathrm{~b}$ & $10.0 \mathrm{ab}$ & $1 \pm 0 \mathrm{a}$ \\
\hline 5 & $\mathrm{NAA} \rightarrow 5 \mathrm{kin}$ & $50.0 \mathrm{a}$ & $0 \mathrm{~b}$ & $20.0 \mathrm{a}$ & $1 \pm 0 \mathrm{a}$ \\
\hline 6 & $\mathrm{NAA} \rightarrow \mathrm{BA}$ & $0 \mathrm{~b}$ & $7.1 \mathrm{ab}$ & $7.1 \mathrm{ab}$ & $2 \pm 0$ a \\
\hline 7 & BA & $8.3 \mathrm{~b}$ & $0 \mathrm{~b}$ & $0 \mathrm{~b}$ & - \\
\hline 8 & Kin & $8.3 \mathrm{~b}$ & $0 \mathrm{~b}$ & $0 \mathrm{~b}$ & - \\
\hline 9 & Kin + shoot & $0 \mathrm{~b}$ & $20.0 \mathrm{a}$ & $0 \mathrm{~b}$ & - \\
\hline
\end{tabular}

Note: 1 = PGR free MS; $2=$ PGR free MS with shoot attached; $3=1 \mathrm{mg} \cdot l^{-1} \mathrm{NAA} ; 4=1 \mathrm{mg} \cdot \mathrm{l}^{-1} \mathrm{NAA}$ for 3 weeks before being transferred to $3 \mathrm{mg} \cdot \mathrm{l}^{-1}$ kinetin (Kin); $5=1 \mathrm{mg} \cdot \mathrm{l}^{-1}$ NAA for 3 weeks before being transferred to $5 \mathrm{mg} \cdot \mathrm{l}^{-1}$ Kin; $6=1 \mathrm{mg} \cdot \mathrm{l}^{-1}$ NAA for 3 weeks before being transferred to 3 $\mathrm{mg} \cdot \mathrm{l}^{-1} \mathrm{BA} ; 7=3 \mathrm{mg} \cdot \mathrm{l}^{-1} \mathrm{BA} ; 8=3 \mathrm{mg} \cdot \mathrm{l}^{-1} \mathrm{Kin} ; 9=3 \mathrm{mg} \cdot \mathrm{l}^{-2} \mathrm{Kin}$ with shoot attached. Figures sharing different letters within the same column indicate a significant difference at $\mathrm{p}=0.05$.

mented with $2 \mathrm{mg} \cdot \mathrm{l}^{-1} \mathrm{BA}$ and $5 \mathrm{mg} \cdot \mathrm{l}^{-1}$ IAA (Figure $4 \mathrm{E}$ and Figure 4F). Shoots of $H$. filiformis responded fairly well in both types of media, whereas those of $H$. acuminata and $H$. argentea turned yellowish after a few days on the PGR free medium. When kept on the same media for a prolonged period the shoots formed cormlets, which could be cut off for generating more shoots. Seedlings also produced cormlets when maintained on the MS medium without PGRs. Acclimatized shoots and seedlings were well established within 3 weeks of transplanting (Figure 5). Shoots of $H$. filiformis seemed to adapt better ex vivo compared to the other two species with $100 \%$ of establishment, while $75 \%$ for $H$. argentea and $16.7 \%$ for $H$. acuminata. 


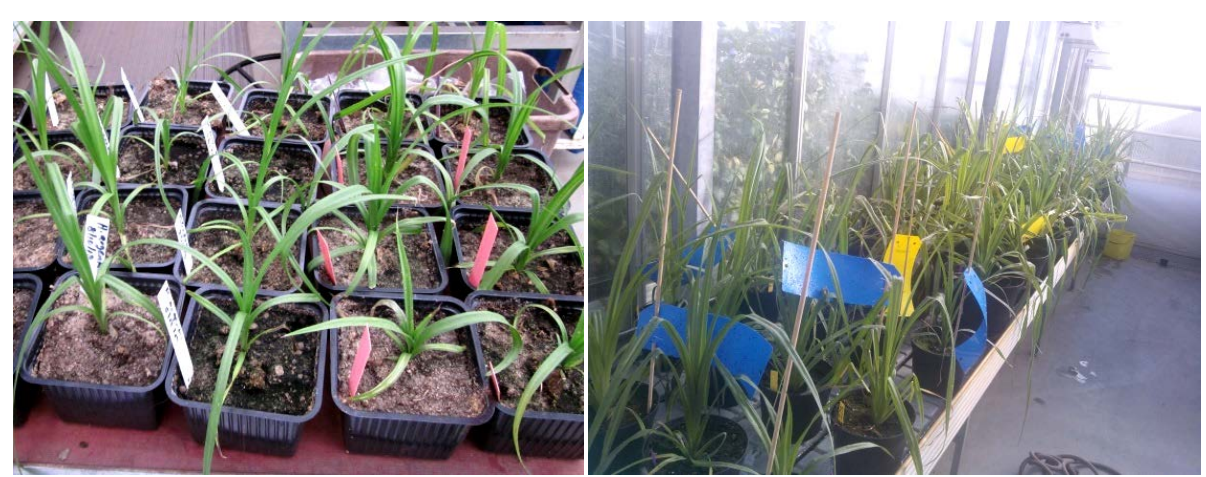

Figure 5. Regenerated plantlets of H.argenteaand H. filiformis 3 weeks after planting (left) and fully grown Hypoxis plants (right) in greenhouse from in vitro culture.

\section{Discussion}

Endogenous pathogens are often a major problem causing failure in in vitro establishment of Hypoxis species, especially when using corms as explants [4] [16] [19]. Our study shows that endogenous pathogens and browning of explants caused by phenolic exudation are the two major sources for the majority of loss of explants during in vitro establishment and regeneration. Once placed on a solidified medium, the explants turned brown or even black rapidly and the medium turned brownish. To prevent browning activated charcoal was added in the medium, and in this study, adding $1.0 \%$ activated charcoal had proved to be effective in reducing the build-up of phenolic exudation in the culture media. In this study, endogenous pathogens of explants contributed to the most loss of the explants during the whole experiment period, especially for corms which were more difficult to decontaminate. Washing infected explants and shoots with a solution of $0.1 \% \mathrm{HgCl}_{2}$ for 5 min helped in clearing almost all noticeable infections, but this treatment can negatively affect growth of the explants.

Germination of Hypoxis is a common problem in practice, apparently due to the hard seed coat or deep dormancy. However, seeds can be a good choice of explants for in vitro establishment as they are relatively easier to be decontaminated compared to corms. Appleton et al. [4] reported that seeds of $H$. colchicifolia failed to establish in vitro with only one seed germinating, which died of browning soon after. In this study, most of the dormancy breaking efforts applied failed to induce seed germination in a preliminary test (unpublished). The only successful attempt for seed germination was crushing the seed coat using forceps, indicating that the hard seed coat is one of the major limiting factors for in vitro germination of Hypoxis species. With this method up to $29.0 \%$ germination was obtained for $H$. argentea. Apart from the hard seed coat, there might be some other endogenous inhibitory factors that affect seed viability as even with the crushed seed coat the germination percentage was still lower than $50 \%$. Previous studies had shown that the viability of Hypoxis seeds varied from season to season [20] [21]. In this study, the seeds used were collected from the plants grown in the greenhouse where the conditions are surely different from their natural growing conditions in southern Africa, and the seeds obtained under the greenhouse conditions might not match the best natural conditions for seed germination.

In vitro establishment and regeneration are affected by types of explants and are genotype/species-dependent. In this study, among all the explant types tested, in vitro establishment and regeneration were obtained only from corms and seeds. Even for the corms the in vitro response varied considerably among the four Hypoxis species, for example, $H$. filiformis was the most responsive as direct shoots were produced from corm explants only 3 - 5 weeks after culture initiation. In contrast, $H$. hemerocallidea showed a much less and slow in vitro response under the same conditions as shoots were obtained 19 weeks after culture initiation, and even when shoots were produced they exhibited an extremely slow growth rate. Vinesi et al. [1] conducted some regeneration tests on three Hypoxis species, $H$. obtusa, $H$. nyasica and $H$. anguistifolia, but only managed to successfully regenerate shoots from corms of $H$. obtusa, suggesting a strong species or genotype dependency for in vitro regeneration of Hypoxis species in general. Although in vitro regeneration has been previously reported from flower buds, in this study flower buds failed to establish in vitro. According to our results, among all types of explants tested, corms appear to be the most suitable explants for in vitro regeneration, followed by seeds.

The presence and concentrations of PGRs in the media were at most influential during culture initiation and establishment as well as for shoot multiplication. Corm explants of some species could produce shoots on the MS without PGRs, for instance, regeneration of corm explants was obtained in $H$. filiformis and in $H$. argentea. 
However, the higher multiplication rate in corm explants could only be achieved with the addition of PGRs; in some instances, like in the case of $H$. acuminata, first culturing corm explants on PGR free basal MS medium before transferring to PGR containing medium seemed to positively influence the regeneration process. Almost all corm explants responded fairly well to in vitro regeneration when cultured with a piece of shoot attached in the presence of PGRs; $100 \%$ and $80 \%$ indirect regeneration was achieved in $H$. filiformis when explants were cultured on MS supplemented with $3 \mathrm{mg} \cdot \mathrm{l}^{-1}$ kinetin and $3 \mathrm{mg} \cdot \mathrm{l}^{-1} \mathrm{BAP}$, respectively. The highest regeneration of $70 \%$ in $H$. argentea was also obtained when $3 \mathrm{mg} \cdot{ }^{-1}$ BAP was added into the basic MS medium; however, this was not the case with the other two species tested in this study. Even without the presence of PGRs, corm explants cultured with shoot performed better compared to those cultured without in H. acuminata, H. argentea, and $H$. filiformis. These results clearly indicate that plant growth regulators play a crucial role in the in vitro regeneration of Hypoxis species, and such effects are species or genotype-dependent. In addition, leaving a piece of shoot attached to the corm relatively enhanced regeneration.

In vitro regeneration using corm explants could occur by direct shoot formation or indirect multiple shoot formation via shoot organogenesis from calli. In view of mass propagation, indirect shoot formation is desirable as a high multiplication frequency could be achieved on condition that somaclonal variation is not present. As high concentrations of cytokinins combined with auxins usually help to induce callus production, a two-step procedure had been used in previous studies, that is, induction of organogeniccalli on callus induction medium (CIM) followed by shoot production on the shoot induction medium (SIM). Using this procedure, Appleton and van Staden [6] reported that high growth response was achieved when $H$. hemerocallidea corm explants were cultured on the initiation medium comprising MS with $1 \mathrm{mg} \cdot \mathrm{l}^{-1} \mathrm{NAA}$ and $1 \mathrm{mg} \cdot \mathrm{l}^{-1} \mathrm{BA}$, but they did not provide any information about the shoot regeneration frequency. Ndong et al. [2] were able to achieve $100 \%$ regeneration efficiency in corm explants of $H$. hemerocallidea with 5 - 8 direct shoots on the MS supplemented with 3 $\mathrm{mg} \cdot \mathrm{l}^{-1} \mathrm{Kin}$, while more efficient indirect regeneration was achieved by the two step cultures, i.e. on CIM with 3 $\mathrm{mg} \cdot \mathrm{l}^{-1} \mathrm{Kin}$ and $1 \mathrm{mg} \cdot \mathrm{l}^{-1} \mathrm{NAA}$, and then on SIM with $1.5 \mathrm{mg} \cdot \mathrm{l}^{-1} \mathrm{BA}$ and $0.5 \mathrm{mg} \cdot \mathrm{l}^{-1} \mathrm{NAA}$. In this study no shoots were produced when $H$. hemerocallidea corm explants were directly cultured with either $3 \mathrm{mg} \cdot \mathrm{l}^{-1} \mathrm{BA}$ or Kin, whilst direct regeneration of $20 \%$ with low shoot number was achieved in corm explants when initially cultured on the basal medium supplemented with $1 \mathrm{mg} \cdot \mathrm{l}^{-1} \mathrm{NAA}$ followed by culture on $5 \mathrm{mg} \cdot \mathrm{l}^{-1} \mathrm{Kin}$. This discrepancy might be due to the different physiological status of initial materials used in both experiments. Alternatively it could also be due to the genotype difference, which often affects in vitro regeneration greatly. Results from $H$. filiformis show that the highest regeneration (100.0\%) was obtained from the basal medium supplemented with $3 \mathrm{mg} \cdot \mathrm{l}^{-1} \mathrm{Kin}$, however, the highest shoot multiplication ratio (17 shoots/explant) was also achieved in the absence of NAA, when explants were directly cultured on the MS medium containing $3 \mathrm{mg} \cdot \mathrm{l}^{-1} \mathrm{Kin}$ (Table 4) suggesting that for some Hypoxis species addition of NAA may not be necessary for initiating regeneration. This indicates that the endogenous auxin level might be sufficient for initiating the regeneration process.

\section{Conclusion}

In conclusion, we have shown a successful establishment of in vitro materials for all 4 Hypoxis species, in which $H$. filiformis has not been reported earlier for in vitro regeneration. Our results have shown that in vitro response of Hypoxis is species or genotype dependent with $H$. filiformis being the easiest one to establish, and $H$. hemerocallidea the most difficult. Among all types of explants tested, corms showed a great potential for in vitro mass propagation as they showed high shoot regeneration frequency and produced multiple shoots for most of the species tested. Seeds could be established in vitro after crushing the seed coat and could be used as explants for micropropagation. Addition of auxins or cytokinins is necessary for shoot regeneration and multiplication in most cases. Attachment of shoot to explants enhanced in vitro establishment in some instances, suggesting that this effect is genotype or species dependent. The rooted and acclimatized shoots from in vitro culture were successfully established in the greenhouse. The successful in vitro and ex vitro establishments of these Hypoxis species indicate clearly the great potential of this vegetative propagation method to conserve them and to prevent their imminent depletion in the future.

\section{Acknowledgements}

We wish to thank Mr Zacharia Dlamini, National Herbarium Curator, Ministry of Agriculture, Swaziland for his assistance with identification of the Hypoxis species; the staff of the National Plant Genetic Resources Centre and Mushroom Development Unit, Swaziland with assistance in collecting plant material; and Dr. Moneim Fatih, 
Project Coordinator in SLU for suggesting the research problem and his support to this study. This study is financed by Sida (Swedish International Development Cooperation Agency) as part of the Nordic support to the SADC Plant Genetic Resources Project.

\section{References}

[1] Vinesi, P., Serafini, M., Nicoletti, M., Spanò, L. and Betto, P. (1990) Plant-Regeneration and Hypoxoside Content in Hypoxis-Obtusa. Journal of Natural Products, 53, 196-199. http://dx.doi.org/10.1021/np50067a031

[2] Ndong, Y.A., et al. (2006) Efficient in Vitro Regeneration of Fertile Plants from Corm Explants of Hypoxis Hemerocallidea Landrace Gaza-The “African Potato”. Plant Cell Reports, 25, 265-273. http://dx.doi.org/10.1007/s00299-005-0060-y

[3] Singh, Y. (2007) Hypoxis (Hypoxidaceae) in Southern Africa: Taxonomic Notes. South African Journal of Botany, 73, 360-365. http://dx.doi.org/10.1016/j.sajb.2007.02.001

[4] Appleton, M.R., Ascough, G.D. and Staden, J.V. (2012) In Vitro Regeneration of Hypoxis colchicifolia Plantlets. South African Journal of Botany, 10.

[5] Kocyan, A., et al. (2011) Molecular Phylogenetics of Hypoxidaceae-Evidence from Plastid DNA Data and Inferences on Morphology and Biogeography. Molecular Phylogenetics and Evolution, 60, 122-136. http://dx.doi.org/10.1016/j.ympev.2011.02.021

[6] Appleton, M.R. and van Staden, J. (1995) Micropropagation of Some South African Hypoxis Species with Medicinal and Horticultural Potential. Ornamental Plant Improvement, 75-77.

[7] Bredenkamp, M.W., Drewes, S.E. and Wentler, G.L. (1989) Medicinal-Plants of Southern-Africa. 3. A Geraniol Glycoside from Hypoxis-Acuminata. Phytochemistry, 28, 263-265. http://dx.doi.org/10.1016/0031-9422(89)85053-8

[8] Drewes, S.E., et al. (2008) Hypoxis Hemerocallidea-Not Merely a Cure for Benign Prostate Hyperplasia. Journal of Ethnopharmacology, 119, 593-598. http://dx.doi.org/10.1016/j.jep.2008.05.027

[9] Van Wyk, B.E. (2011) The Potential of South African Plants in the Development of New Medicinal Products. South African Journal of Botany, 77, 812-829. http://dx.doi.org/10.1016/j.sajb.2011.08.011

[10] van Wyk, B.E. (2008) A Broad Review of Commercially Important Southern African Medicinal Plants. Journal of Ethnopharmacology, 119, 342-355. http://dx.doi.org/10.1016/j.jep.2008.05.029

[11] Nair, V.D.P., Dairam, A., Agbonon, A., et al. (2007) Investigation of the Antioxidant Activity of African Potato (Hypoxis hemerocallidea). Journal of Agricultural and Food Chemistry, 55, 1707-1711. http://dx.doi.org/10.1021/jf0619838

[12] Boukes, G.J., van de Venter, M. and Oosthuizen, V. (2008) Quantitative and Qualitative Analysis of Sterols/Sterolins and Hypoxoside Contents of Three Hypoxis (African Potato) Spp. African Journal of Biotechnology, 7, 1624-1629.

[13] Bredenkamp, M.W., Drewes, S.E. and Wentler, G.L. (1989) A Geraniol Glycoside from Hypoxis acuminata. Phytochemistry, 28, 263-265. http://dx.doi.org/10.1016/0031-9422(89)85053-8

[14] Yang, S.-W., Zhou, B.-N., Wisse, J.H., et al. (1998) Three New Ellagic Acid Derivatives from the Bark of Eschweilera coriacea from the Suriname Rainforest1. Journal of Natural Products, 61, 901-906. http://dx.doi.org/10.1021/np980046u

[15] Appleton, M.R. and van Staden, J. (1995) In Vitro Propagation of a Miniature Hypoxis, H. angustifolia. Ornamental Plant Improvement, 420, 95-97.

[16] Page, Y.M. and Vanstaden, J. (1984) In Vitro Propagation of Hypoxis rooperi. Plant Cell, Tissue and Organ Culture, 3, 359-362. http://dx.doi.org/10.1007/BF00043088

[17] Page, Y.M. and Vanstaden, J. (1986) In Vitro Propagation of Hypoxis Rooperi from Flower Buds. South African Journal of Botany, 52, 261-264.

[18] Murashige, T. and Skoog, F. (1962) A Revised Medium for Rapid Growth and Bio Assays with Tobacco Tissue Cultures. Physiologia Plantarum, 15, 473-497. http://dx.doi.org/10.1111/j.1399-3054.1962.tb08052.x

[19] Suri, S.S., Jain, S. and Ramawat, K.G. (1999) Plantlet Regeneration and Bulbil Formation in Vitro from Leaf and Stem Explants of Curculigo orchioides, an Endangered Medicinal Plant. Scientia Horticulturae, 79, 127-134. http://dx.doi.org/10.1016/S0304-4238(98)00118-6

[20] Hammerton, R.D. and Vanstaden, J. (1988) Seed-Germination of Hypoxis hemerocallidea. South African Journal of Botany, 54, 277-280.

[21] Gillmer, M. and Symmonds, R. (1999) Seed Collection and Germination: Hypoxis hemerocallidea (Hypoxidaceae). Plantlife, 21, 36-37. 